\title{
The transformation of the LATin American State-As-LaW: State Capacity and the Rule of LAW*
}

La transformación del estado de derecho latinoamericano: Capacidad del Estado y estado de derecho

\section{DANIEL M. BRINKS}

University of Texas at Austin

\begin{abstract}
The article maps a profound transformation in the nature of the state-as-law in Latin America since 1975. In 1975, states had legal orders with limited ambition and limited autonomy from the ruler of the day. There were vast social, economic and political spaces left open to arbitrary decision making. Now these spaces have shrunk, and state order had become more formalized. We can now distinguish four models of state-as-law, depending on the density and autonomy of the state's legal order: the original model (an estado politico) survives in a very few states, and three new models have emerged, an estado social de derecho, an estado liberal de derecho, and an estado de derecho politizado.
\end{abstract}

Key words: State, Rule of Law, State Capacity, Rights, Legality.

\section{RESUMEN}

Este artículo propone que hubo una profunda transformación en la naturaleza del estado de derecho en América Latina desde 1975. En esa época, el Estado proponía una legalidad muy acotada y con poca autonomía de quien detentaba el poder. Existían vastos espacios sociales, económicos y políticos librados a la arbitrariedad del poder. Ahora, estos espacios se han reducido, y el orden se ha formalizado. Podemos distinguir cuatro modelos de estado de derecho, dependiendo de la densidad y autonomía del orden legal: el modelo original, un estado político, que persiste en pocos estados, y tres nuevos, el estado social de derecho, el estado liberal de derecho y el estado de derecho politizado.

Palabras clave: Estado, estado de derecho, capacidad del Estado, derechos, legalidad.

* This paper was first presented at the Conference on "Stateness" in Latin America in the 21st Century: Conceptual Challenges, Santiago, Chile, March 29-30, 2012. I am grateful to the participants in that conference for their input and comments, and for the opportunity to think through these issues in the context of very stimulating discussions. I am also grateful to an anonymous reviewer for helpful suggestions. This article is part of the Millenium Nucleus for the Study of Stateness and Democracy in Latin America, Project NS100014, of the Ministry of Economy and Tourism of Chile. 
The question of state capacity underlies questions that run from the current surge in violent crime to the ineffectiveness of indigenous land rights, from the misuse of public office for private gain to the inability of women to enforce their right to child support. In Latin America these challenges are both perennial and located in a rapidly shifting political terrain that has redrawn the topography of the legal state over the last thirty-five years. In this article I make a series of mostly analytical-descriptive points to clarify several related concepts such as state capacity and the strength or weakness of a state, particularly in its legal dimension. First, I argue that much of what is often presented as a general problem of state weakness -for example, the inability to collect taxes-can be described as a specific instance of failure of the rule of law. Next I elaborate on this, using the definition of the rule of law to map types of normative regimes along two dimensions -a vertical one, in which the regimes govern rights and obligations that run between the state and citizens, and a horizontal one, where the regimes govern interactions among citizens. I use that conceptual map to suggest that different types of regimes pose very different practical and political challenges for states in establishing the rule of law, and that we should, therefore, develop theories that address these differences.

Finally, I use these concepts and dimensions to argue that there has been a profound transformation in the nature of the state-as-law in Latin America since 1975. At the beginning of the period, states had legal orders with limited ambition and limited autonomy from the ruler of the day. There were vast social, economic and political spaces left open to arbitrary decision making by local or national powerholders, and the state's order was often poorly and incompletely inscribed in state law. By the end of the period these spaces have shrunk, for good or ill, and state order has become more formalized. We can now distinguish four models of state-as-law, depending on the density and autonomy of the state's legal order: the original model (an estado politico) survives in a very few states, and three new models have emerged, an estado social de derecho, an estado liberal de derecho, and an estado de derecho politico (or politizado). I elaborate on these models below.

\section{ON LAW, RULE OF LAW, AND STATE CAPACITY}

The first point is that we should, as Weber (1978 [1921]) pointed out long ago, understand the state as nothing more mysterious than an organization -a special kind of organization, to be sure, with some attributes that distinguish it from other organizations, but an organization nevertheless. It is the organization that has, among other attributes, the right, granted by the relevant sovereign, to exercise force if necessary to defend its "order" within a given territory. The order (preferably enacted by the government) specifies the goals and means that will be used to manage a certain population and territory- it prescribes certain actions, proscribes others, and grants freedom regarding still others. The state order is specified in the state's legal system and in informal rules that condition or expand the reach of that legal system. As a result, it seems right to consider the law an integral part of the state (as O'Donnell, 2010; 2001 pointed out), and successfully upholding the rule of law an integral part of what it means to be a successful state. 
The state's order, as we will see below, consists largely of a set of rights and obligations that run among citizens or between citizens and the state (and a series of ancillary rules concerning enforcement, the making and changing of rules, and so on, that surround and underpin those rights and obligations). ${ }^{1}$ It specifies, for instance, how much a citizen must pay in taxes, what procedures the state must follow before taking citizens' property and what the state is supposed to do with that property once it has it. It describes the resources each citizen is entitled to receive from the state. Importantly, it also specifies what the consequences are when one citizen trespasses on another's property or freedom, and what obligations citizens owe to each other. The extent to which this matrix of interactions is structured by state law is central to the question of state capacity.

This is not to say that the state must always exercise force to make its order effective, that it cannot authorize others to also use force under certain conditions, or that it cannot cede some part of that right to make and enforce a particular set of rights and obligations to outside, even foreign (or subnational) actors. In other words, the potential for state coercion is something that for the most part runs deep in the background of everyday life, whether the state reserves the right to enforce a particular right or grants enforcement capacity to private actors. Even when the state takes a step further back, delegating enforcement to a third party, it retains the capacity to enforce that third party's right to enforce (and to enforce the limits on that right). So, for example, we each have the right to enforce (or not) our contractual rights, but the state backs that right with a judicial system we can use to sue a debtor, police protection when the irate debtor tries to prevent us from enforcing our rights, and debtor's rights legislation when we overstep our bounds.

What does law have to do with state capacity? Simply that law -state order-plus the informal norms the state is willing to permit, to a large extent determines what is a challenge to the state and what is a state purpose, what the state seeks to accomplish and what it leaves to private efforts. It is thus constitutive of the state - it establishes state purposes, defines challenges and challengers, describes and sets up state structures, and establishes the entitlements, rights and obligations of residents, which the state commits to backing with its resources. Law, including the sublegal regulatory framework that structures the state's decision-making processes, is what defines the organization that is the state, assigning roles, duties and obligations in the bureaucracy, as well as the relationship between the state and its population. In addition to being an output of the state, therefore, law is an attribute of the state, as O'Donnell (1993) suggested. The clear implication of this is that the extent to which "law rules" -that is, the extent to which the state seeks and is able to impose its order- is an essential dimension of state capacity.

Since what is at stake here is simply state capacity, and not "democratic" state capacity, we can proceed with a minimalist definition of the rule of law. There has been a great deal of ink spilt bemoaning the difficulty of adequately defining the rule of law (see

1 The taxonomy of types of laws is, of course, more complex than this implies, as H.L.A. Hart (1961) and Ellickson (1991) have noted. But the other types of rules they identify are at the service, ultimately, of these substantive rules -controller-selecting rules, for instance, ultimately exist so that we know where the authoritative decisions can be made on rights and obligations in a particular instance. 
Domingo and Sieder, 2001; Kleinfeld, 2006; Santos, 2006; O'Donnell, 2004; Trebilcock and Daniels, 2008), but much of that only becomes an issue if one is intent on looking for a normative component to the rule of law. If one is willing to be normatively agnostic, the definitional problem is vastly simplified. A commonly used minimal and thin conception of the rule of law borrows from Rawls: "the impartial and regular administration [by the state, presumably] of rules, whatever these are" (Rawls, 1971: 235 [quoted in Trebilcock and Daniels, 2008: 20]). But a minimalist definition should include more than the effective application of rules by the government -what might be called rule by law (Holmes, 2003)- to reflect both a horizontal and a vertical dimension. The rule of law implies that law structures not only interactions with the state- the vertical dimension -but also those between citizens- the horizontal dimension (see, e.g., Magaloni, 2003: 269-271).

We can capture both dimensions in one definition of the rule of law, using a slightly more expansive but still thin definition: the rule of law is prevalent to the extent that regulated interactions among citizens or between them and the state are structured by (that is, predictable according to) preexisting rules that have the status of law within that political system. This definition requires not only compliance with the law by official instances, both in the conduct of official duties and in interactions with citizens, but also substantial compliance with the law by citizens in their ordinary affairs and interactions. The lack of substantive requirements in the thin definition allows us to examine various interesting questions, including, for example, whether the rule of law, regardless of the law's substantive justice, eventually leads to more democracy, or more justice, or more regard for human rights. Although the ultimate goal might be to develop, as O'Donnell (2010) suggests, a democratic rule of law, or a more just rule of law, this definition is more suitable to empirical investigations of the effects of the rule of law. ${ }^{2}$

The only substantive requirement in this definition is that these laws be preexisting the alternative would allow a ruler to dress up arbitrary, ad hoc, rule in legal clothing. Another way of stating the preexistence requirement is that the law must have some autonomy, a point we will take up in more detail below. The standards set in the law must pre-exist the conduct in question or they become no more than the ad hoc reactions of the ruler to past actions, rather than rules that can structure those actions. Moreover, the application of those rules, by the police, the courts, or whoever, must have sufficient autonomy, or, once again, the rules become so malleable as to be no more than reactions to conduct that is evaluated post hoc. This is not to say that the law will always lead to perfectly predictable outcomes, or that there is not a great deal of indeterminacy built into every legal framework. But even that indeterminacy must be structured by a sort of professional logic of the law, which may differ from country to country but will be

2 "Institutional" definitions of the rule of law retain this substantive agnosticism but typically specify a set of institutions that must be present for a state to have the rule of law (Trebilcock and Daniels, 2006, citing Raz, 1979: 211-14). In my view, these are not so much definitions as a prescription for what must be done if law is to fulfill its intended social coordination function. A truly "thick" definition of the rule of law, meanwhile, specifies at least some of the values that must be protected by the laws. Typically these might include human rights, or broader notions of substantive justice - thus not only requiring that everyone be granted the same rights, but also specifying some minimal list of rights that must be included in the system of laws (Kleinfeld, 2006). 
more or less stable over time. This brief discussion glosses over what is obviously a vast literature that runs from legal realism to classic formalism; from the ideal of judges as servants of the law to the attitudinal model of judicial behavior (on this last point see, e.g., Segal and Spaeth, 2002). We return to the discussion of legal autonomy toward the end of the article. For now, it is sufficient to note that the definition anticipates a variably dense network of rules regulating a vertical and a horizontal dimension as well as some degree of autonomy.

\section{ON THE DIVERSITY OF CHALLENGES POSED BY THE RULE OF LAW}

Once we highlight the rule of law's two-dimensional framework, it is obvious that the state's order is comprised of different types of legal regimes that vary depending on whether the obligations run vertically or horizontally, and on the direction in which they run. The state - through individual public actors - owes duties, and is the beneficiary of duties owed by private actors, and vice versa. Private citizens owe duties to each other, and are, in turn, the beneficiaries of these duties. The state's role in enforcing these mutual duties is less visible and direct, but by no means negligible. It provides the structures, and ultimately the threat of coercion, that prompt compliance and assist in enforcement.

Each of these cells poses very different challenges for the state, and responds to a different politics. Our theories of what produces state capacity should respond to this diversity as well. For example, it is one thing to monitor and discipline private behavior and another to monitor and discipline the behavior of other state actors. The former poses possibly greater logistical challenges, in terms of monitoring and enforcement. The latter, however, likely poses greater political challenges, requiring some diversity of interests within the state, as we will see. Keeping these kinds of duties separate when measuring or trying to account for successes and failures is likely to produce better measures and better theories.

Most generally, at the top of the table, it is state actors who are resisting compliance, and thus, the politics of directing state activity should matter directly - state enforcement

Table 1: Classifying legal regimes, by the direction of duties owed between state and citizens, with examples

\begin{tabular}{llll}
\hline & & \multicolumn{2}{c}{ Duty owed to } \\
\cline { 3 - 4 } & \multicolumn{1}{c}{$\begin{array}{c}\text { The state } \\
\text { The state } \\
\text { (through state }\end{array}$} & $\begin{array}{l}\text { "Horizontal accountability:" } \\
\text { anticorruption laws, separation of } \\
\text { powers, limits on executive power }\end{array}$ \\
$\begin{array}{l}\text { Duty } \\
\text { actors) }\end{array}$ & $\begin{array}{l}\text { Constitutional rights, } \\
\text { administrative law, human } \\
\text { rights, welfare entitlements }\end{array}$ \\
& Private actors & Criminal law, taxation & $\begin{array}{l}\text { Contracts, torts (negligence, } \\
\text { etc.), property law, family } \\
\text { law, business law }\end{array}$ \\
\hline
\end{tabular}


action pits one set of state actors against another. In the bottom row, on the other hand, it is private actors who will resist enforcement efforts, and thus the resources and capabilities of the different social groups burdened by the laws should matter directly. In this row, politics still matters but indirectly, through the politics of state creation, because this determines the quantum of state resources dedicated to enforcement, as well as the nature of the duties being enforced. On the left side of the Table, where duties are owed to the state, state enforcement capacity matters very directly. On the right, where duties are owed to private actors, the resources of the social groups entitled to enforce the rules matter directly, whether for private enforcement or for engaging with state backup structures.

Taking the cells one at a time, in the northwest quadrant of the table, where state actors owe the state duties, the state's capacity to make its laws effective has much to do with the relative autonomy of one part of the state from another. Effectiveness will depend, for example, on whether prosecutors and the judiciary are sufficiently independent of the executive branch to investigate and prosecute any violations. And the relative autonomy of one part of the state from another is a function, at least in part, of institutional design and a healthy level of political competition - separation of functions coupled with the separation of interests, so that the ambition of one set of state actors can be made to check the ambition of another set, to paraphrase the Federalist Papers (Hamilton et al., 1961). This is a problem of politics more than a problem of resources. The crucial problem in this quadrant is not monitoring remote sectors of society, reaching out to areas where the state is not present, or overcoming the resistance of powerful state challengers; rather, it is finding the motivation in one sector of the state to enforce duties against another.

On the other hand, in the southeast quadrant, where private actors owe duties to other private actors, it is clear that the answer is more a problem of relative resources, a function of socio-economic inequality within the dyad defined by the laws. Voluntary compliance with rules might depend in part on the sense of appropriateness of obeying the duty (Tyler, 2006), or a feeling of reciprocity (Stone Sweet, 1999), the notion that no one is exempt from the rules (Levi, 1988), or when all else fails the sense that the other can bring negative consequences to bear (Maravall and Przeworski, 2003). In any of these cases, a sense that the other is roughly a social and economic equal should contribute significantly to greater compliance with the duties. Even when the aggrieved party must make resort to state enforcement mechanisms, that party's success depends to a large extent on the individual effort of the rights bearer vis-à-vis the duty bearer (Brinks, 2008; Brinks and Botero, forthcoming).

The politics of state creation matter too, of course -most states devote a great deal of their resources and structures to assisting individuals in the protection of their property rights, for example, and this is a function of politics- but they matter indirectly, by conditioning the nature and extent of state aid extended to the beneficiaries of a particular right. And even here, these politics are influenced 
by the social, political and economic resources of the group in question. In this cell, then, the crucial issue is the inequality of resources between the nominal beneficiaries of a legal right and those on whom that right imposes a burden. The problem is political here only indirectly: the state could, if so directed, dedicate more resources to assisting claimants in their demands when their private resources fail them.

The answer for the mixed regimes of the southwest and northeast cells is more complex. In the northeast, individual capacity still plays a large role. Truly marginalized populations, with little political clout and limited resources with which to engage legal enforcement mechanisms, will struggle to make their rights effective vis-à-vis state actors. We might then assume this is mostly a question of individual resources. But it is equally true that in order to succeed these claimants must engage one part of the state-courts, prosecutors, auditors, ombuds offices, perhaps- to monitor another. Thus these regimes pose all the resource problems of the southeast cell and all the political problems of the northwest cell.

Finally, in the southwest corner of the table we have regimes that require society to bend its will to the state's orders, and are often viewed as the signature issues of state capacity -taxation and social order, for example. Here, we often assume, the problem is not political but resource-based: does the state have the institutional and organizational resources, the legitimacy and credibility, the human capital among its agents, to effectively collect taxes, enforce criminal law, require people to serve in the military, and so on. In this quadrant, it seems, the answer has to do with the balance of power between the state and particular sectors of society. Powerful social actors -economic or criminal groups, for example- can resist efforts by the state to monitor and enforce its order. This quadrant also requires the greatest amount of state penetration of society for monitoring and enforcement, since here the entire burden rests on society while the benefit devolves most immediately upon the state. ${ }^{3}$

But politics of course matters a great deal in this quadrant as well. It is quite often the cumulative effect of political decisions that leaves the state weak vis-à-vis powerful economic actors, and thus unable or unwilling to collect taxes, and strong to monitor and repress particular populations. The state is selectively produced in response to demands. It is in part its political history that determines the capacity a state develops for policing some areas and not others, some kinds of crime and not others.

This last observation suggests that there are two aspects to the development of an effective legal order. One, which is most directly implicated in Table 1, is the density of state order - the extent to which the state seeks to regulate diverse areas of human activity, and different kinds of interactions. Some states regulate deeper into society,

As an aside, here is where the idea of the state-for-the-nation is likely a very important state resource, since only such an idea can enlist citizens as voluntary compliers, or as voluntary monitors of the compliance of others. 
while others leave more space for unregulated citizen interactions, deferring to the market or the family or even religion, say, for structuring those relationships. Some legal orders leave states more constrained, with more detailed restraints on state actors, while others allow more discretionary or even arbitrary action on the part of state actors. The other aspect, which I called autonomy in the earlier discussion of the definition of the rule of law, is the extent to which these regulations are enforced according to their internal logic, versus the post hoc logic of momentary expedience. I turn to these two dimensions next. They will condition the way in which the rule of law operates across all the cells of Table 1.

\section{ON THE DENSITY AND AUTONOMY OF THE LEGAL STATE}

The idea of legal autonomy ties into the definitional requirement laid out earlier - for the rule of law really to exist, the rules that structure interactions between state and citizen must be pre-existing. The ruler cannot claim to be applying rules if it invents a new "rule" every time it decides on a conflict that involves its interests. By the same token, the ruler cannot claim to be following the law if it effectively invents a new rule without changing formal rules, by simply offering new, self-serving interpretations of the rules for every new conflict. To have a meaningful version of the rule of law, therefore, the law in its application must possess a certain degree of autonomy from outside power structures -in particular, from the current ruler or whoever is charged with applying it. In practical terms, this means the interpretation and application of the law to particular situations must respect the professional logic of law, rather than bowing in every case to the political exigencies of the moment. ${ }^{4}$

An autonomous legal order, enforced through autonomous legal institutions, contributes to state strength in very real ways. Like any other bureaucracy, courts -real, strong, courts- can provide many benefits to a regime, whether authoritarian or democratic, including facilitating social control, monitoring bureaucratic behavior, legitimizing regime decisions, and the like, with comparatively fewer costs and lower risks than other mechanisms (Shapiro, 1981; Moustafa, 2007; Ginsburg and Moustafa, 2008; Hirschl, 2004). Powerful courts are an essential element of state capacity for at least three reasons. First, understood as a bureaucracy, a judiciary that is more effective, efficient, and autonomous is simply a higher quality bureaucracy. It carries out the "orders" of the ruler (i.e., the laws, decrees, etc.) in the most effective manner, with the least agency drift. Second, such a judiciary is an essential component of the rule of law. While, as noted, the rule of law is a notoriously contested concept, nearly all conceptions of it place an independent, effective judiciary at the center. And third, a judiciary that is widely perceived as impartial

4 Of course, we should not overstate the distinction between "law" and "politics", or even between "interpretation" on the one hand, and "ad hoc decision-making" on the other, as there is ample space in the most "professional" legal logic, and the crispest legal text, for "political" considerations of various sorts. But in every legal system there is a more or less fuzzy boundary between what might be a legal process and what would be considered a politicized or purely political one. 
is an important component in ensuring the legitimacy of the state and its legal order, thus facilitating the state's efforts to extract resources and impose order.

Thus far, I have spoken only of autonomy of the law and of courts. And, in fact, most studies of courts tend to assume that the interesting dependent variable is "judicial independence", and that it is uni-dimensional. Similarly, there is a longstanding debate about the relative autonomy of the law (see, e.g., Tomlins, 2007). But it is clear that we need another dimension to fully evaluate the strength of the legal state. A legal system may be very autonomous (or independent, or any other partially equivalent term), but may still leave vast areas of social activity outside its regulatory scope. A given system may emphasize one or more of the cells in Table 1 but leave others essentially unregulated, or it may specify few rights and obligations across all the cells in the table. Indeed, one occasionally hears complaints that a system has "too many laws" or is overregulated, by which is often meant that it imposes too many duties on individuals vis-à-vis the state, but which could mean overregulation in any of the cells in Table 1. To take the full measure of the strength of the legal state we must consider this other dimension as well, which we could call the density of regulation or the scope of the regulatory state. This is most visibly manifested in what we have elsewhere called a court's scope of authority (Blass and Brinks, 2011).

It is increasingly evident that, over the last thirty-five years or so, the regulatory ambition of some Latin American states has increased significantly in both geographic and functional terms. In some cases, of course, neoliberal reforms initially shrunk the functional ambit of state legality, leaving more room for a market logic, even as property rights protection and market regulation aspired to be more autonomous. In most countries, however, even as the welfare state shrank, new regulations have emerged, dealing with the environment, or constitutionalizing social and economic rights, or seeking to address traditional forms of discrimination against women or ethnic minorities. This regulatory density dimension is, in theory, independent of the autonomy dimension, and must be addressed separately. ${ }^{5}$

In terms of Table 1, what this means is that more and more interactions are regulated directly by state law, in all four quadrants, rather than being left to private arrangements or discretionary action by state agents. Moreover, many interactions that were lightly regulated and located in the purely private southeast cell (e.g., because they were left to freedom of contract) have been added to the northeast cell where there are state duties to private individuals (e.g., because the government must now guarantee certain minimum standards for that relationship). This densification happened long ago with labor relations in most countries - prompting reactions such as French's (2004) "Drowning in Laws"but is now extending to many other areas. With each constitutional reform in Latin America, states have taken on additional duties in the form of new constitutional rights or human rights treaties. With each passing year, the relationship between spouses or between parents and their children is more and more subjected to state regulation. The use and exploitation of vast territories once considered free for the taking is now subjected 
to the rights of indigenous groups and environmental protections. Domestic workers are gaining legal protections; racism and sexism are increasingly regulated; consumer protections are being legalized. The brown areas O'Donnell (1993) so vividly described, where state legality is absent and replaced with private orderings, are shrinking. This is not to say all these laws secure perfect compliance -no laws anywhere do that in any event- but state legality has gained in both geographic extension and substantive density. States still fail to extend the same protection across social classes, but even here, as the indigenous rights example suggests, things are improving, at least in some countries.

These two dimensions of state legality -density and autonomy-allow us to classify the states that emerge as having (or tending toward, as these dimensions are self-evidently continuous) four distinctive ideal typical legal orders.

Table 2: Four ideal types of legal states, depending on levels of autonomy and regulatory density

\begin{tabular}{lll}
\hline & \multicolumn{1}{c}{ Low autonomy } & \multicolumn{1}{c}{ High autonomy } \\
\hline High Density & $\begin{array}{l}\text { Politicized legalism/estado de } \\
\text { derecho politizado }\end{array}$ & Thick rule of law / estado social de derecho \\
Low Density & $\begin{array}{l}\text { Extra-legal policy making and } \\
\text { implementation/estado politizado }\end{array}$ & Thin rule of law/estado liberal de derecho \\
\hline
\end{tabular}

At the high end of autonomy we might find countries that are embracing either a thin version of the rule of law, as have the more market-oriented states, or a thick one, as have the more social democratic ones (see Rodríguez Garavito, 2010, for a discussion of this distinction in the context of Colombia). In countries with a dense regulatory state but very low levels of autonomy, we might find that the governments are simply using the courts to give a veneer of legality to ad hoc political decisions that penetrate deeply into society and the market. Where law has neither broad scope nor autonomy, on the other hand, courts and law are relatively tangential to policy making and implementation. Here the state manages its population and territory without bothering too much with preexisting rules and legal mechanisms.

To denote these different ideal types of states-as-law, we can qualify the common Spanish phrase for the rule of law, estado de derecho. Colombia and various other countries have adopted a German term, expressly labeling their state an estado social de derecho in the constitution, meaning to denote at least one version of what I call a Thick Rule of Law state. ${ }^{6}$ The Thin Rule of Law state might then be labeled an estado liberal de derecho, while 
a state with politicized legalism might be an estado de derecho politizado, where law is fundamentally political not only in its origins but in its application. The last category is simply an estado politizado, a state that is not acting through law and legal mechanisms to the same extent as the others, but that retains deep control over legal instances, so there is no autonomy even for fundamental claims relating to, say, basic civil and political rights. Note that these are relative terms, as all rulers, even authoritarian ones (Pereira, 2005; Ginsburg and Moustafa, 2008; Moustafa, 2003), will act through law to a significant extent; and all law, even in fully democratic regimes, is deeply embedded in and responsive to political processes. Moreover, the labels are meant to suggest ideal types, rather than to fully describe any actually existing states.

In terms of Table 1, on the density dimension, both the estado liberal de derecho and the estado politizado explicitly regulate fewer of the interactions that would otherwise fall in all four quadrants of the table. At the same time, it seems empirically unlikely that one could successfully ensure autonomy without at least a minimum of due process protections. This implies at least some additional duties upon state actors and thus greater density in the northwest quadrant for the estado liberal de derecho compared to the estado politizado. The other two ideal types, in contrast, purport to densely regulate all quadrants by adding qualifications to individual freedom of contract, limiting the discretion of state actors, and so on. States with less legal autonomy, in turn, might be especially deficient with respect to the legal regimes that fall in the top row of Table 1, and selectively enforce the ones in the lower row to suit political ends. Thus the adoption of one or another of these models is likely to have profound implications for the regime, individual freedom, economic development, inclusion and social welfare -in short, the very texture of social, political and economic citizenship.

How can we empirically translate this conceptual arrangement to the actual states of Latin America? Given that there is not even any consensus on what it might mean for law to be autonomous, it would be difficult to comprehensively and systematically measure the autonomy of "law" directly. One option would be to evaluate the extent to which laws and their application respond to shifts in the political arena - a high degree of instability, ever-changing laws and interpretations, selective enforcement that suits political goals, punitive application of the law to opposition groups, the use of legal instances to monitor unwelcome political activity, rapid changeover of personnel at the highest levels of law enforcement and the judiciary, close personal connections between this personnel and high political officials, all these are markers of politicized legalism. Alternatively, we have argued that autonomy is best understood as impartiality, and, drawing on Holmes (2003), that the closest we can come to achieving impartiality may be through a balance of partialities (Blass and Brinks, 2011: 12). Thus one measure of autonomy, or at least a likely cause of it, is the presence of multiple and balanced inputs into both the way law is made and the way it is applied, by government officials, police officers, judges and so on.

I do not purport to offer a direct measure of density and autonomy in this article. Instead, I will use a formal institutional measure of the autonomy and scope of authority of the country's highest court as a proxy, to produce a first-order, suggestive coding of 
states-as-law in Latin America. The measure is more fully described in several recent papers (Brinks and Blass, 2011b; Blass and Brinks, 2011). As an institutional measure of judicial autonomy and scope of authority, this proxy requires three strong caveats. First, while autonomous courts with broad scope of authority are likely necessary for an autonomous and densely regulated legal state, they are not sufficient. Legal systems are composed of many elements, including but not limited to courts. Second, this is a purely institutional measure, and we know that the way in which institutional design works -even when it works perfectly-is strongly conditioned by the political context, among other things. Many countries, for example, have moved to requiring a two-thirds vote by the senate for approval of judicial appointments. This one rule will tend to produce one result (deadlock or multiple payoffs to small parties) in a highly fragmented context like Ecuador, another (negotiations between majority and opposition) in what is nearly a two-party system like Argentina or Mexico, and yet another (majority-dominated appointments) in a dominant party regime like Venezuela. But, ceteris paribus and on average, such a rule will tend to produce more consensual appointments than one that requires a simple majority vote.

Finally, given the long history of institutional weakness in the region, one might legitimately question whether any institutional arrangements will translate into practices remotely resembling them. But the broad trends in institutional design seem to track changes in behavior. Even a superficial analysis of the literature on Latin American judiciaries suggests that the state of legality has vastly improved over the last 35 years (although substantial room for improvement remains). The dominant theme twenty years ago was perhaps best captured by Mendez et al's. (1999) "The (Un)Rule of Law". Shortly after the publication of that book, however, the tide turned toward books that addressed the "judicialization of politics" in Latin America (Domingo and Sieder, 2001; Sieder et al., 2005; Couso et al., 2010). More recent studies have documented the extent to which courts have turned to the enforcement of social and economic rights incorporated in constitutions (Gauri and Brinks, 2008; Yamin and Gloppen, 2011; Rodríguez Garavito and Rodríguez Franco, 2010); and their ability to change social reality for even seriously marginalized populations (Sieder, 2002). It appears, then, that, at least on the vertical dimension of the rule of law, and on some of the legal regimes that regulate the horizontal dimension, courts are not only acting more autonomously, they are also engaged on a wider range of issues than ever before, and are garnering some level of compliance, even for their more ambitious and contrarian interventions.

In spite of these caveats, therefore, the proxy appears reasonable. Countries that write more autonomous courts into their constitutions are, ceteris paribus, likely to have a more autonomous legal system overall. They are promoting the sort of neutral, impartial model of legal decision-making that is central to most definitions of the rule of law. The scope of authority of the court, meanwhile, is suggestive of how much social conflict is meant to be structured by law and channeled into legal mechanisms -easily accessible courts with a broad portfolio and powerful decision-making tools suggest a model in which social conflict is intended to be resolved through legal mechanisms (whether impartial or not). If the courts are also autonomous, then that resolution is more likely to be according to 
preexisting rules, whereas if the court is an instrument of the executive, the courts will simply be used to legalize/legitimize ad hoc political decisions.

The problem with judicial autonomy (or independence) in Latin America has often been perceived purely as a failure to comply with the formal rules. Thus the perceived weakness of courts was typically not attributed to institutional design, but rather to deeper cultural failures (Rosenn, 1987), or, probably more accurately, to the authoritarian or hyperpresidentialist politics of the region (see, e.g., O'Donnell, 1994 on delegative democracy and the lack of horizontal accountability; Larkins, 1998). Clearly, it is harder for courts to maintain their autonomy under authoritarian regimes. It is also true, however, as noted above, that even such regimes have an interest in establishing powerful courts. And thus, certain authoritarian regimes -Pinochet's regime in Chile is the most frequently cited example- have maintained courts that enforced preexisting rules (Barros, 2003). Others have not: Pereira (2005) has analyzed how different authoritarian regimes placed courts more or less at the center of their repressive projects. These earlier diagnoses largely ignore the institutional roots of judicial autonomy and authority, and the way in which the political impulses to use courts as instruments of the executive are put into practice through institutional design.

Our institutional mapping makes it clear that Latin America's courts were, prior to the 1980s, expressly designed to be less autonomous and less authoritative. In Blass and Brinks (2011) we coded all the institutional features of all the courts in Latin America since $1975 .^{7}$ That study uses a measure of autonomy that estimates the ease with which an outside actor -typically the executive- can control appointments to the courts. The measure is essentially based on the number of veto players involved in the appointment of judges, and assumes that a lower number of veto players makes it easier for the executive to assert control over the courts by naming close associates. ${ }^{8}$ Scope of authority, in turn, is an aggregate measure that takes into account the categories of cases the courts can decide, the types of rights the courts can enforce, the ease of access to the courts, and the formal effects of their decisions (Blass and Brinks, 2011). By this measure, as we see in Figure 1, average levels of autonomy and scope of authority of the region's judiciaries have increased significantly over the last thirty-five years.

By this measure, Latin American courts have become formally more autonomous in their appointment processes, and have gained a much broader scope of authority -their institutional design seems directed toward making them more powerful. Taking this as a proxy for the nature of the legal state, then, Latin American states have, on average, moved in the direction of a Thick Rule of Law state. But, as we will see, there is considerable variation hidden in this trend, as the dip in mean levels of autonomy

7 The features are those of the highest court, not the lower courts in each country, but (a) the lower courts often share the same features, and (b) lower courts are typically only as independent as their high courts, since they ultimately respond to the judicial hierarchy.

8 Brinks and Blass include another dimension -sometimes labeled "accountability", although technically it measures "non-accountability" since higher numbers suggest less accountability- which measures the ease with which an outside actor can discipline or punish sitting judges. For simplicity, I use only the measure they label ex ante autonomy. 
Figure 1: Regional means of Autonomy and Authority, measured as changes from the 1975 regional mean, for all courts in Latin America, 1975-2009

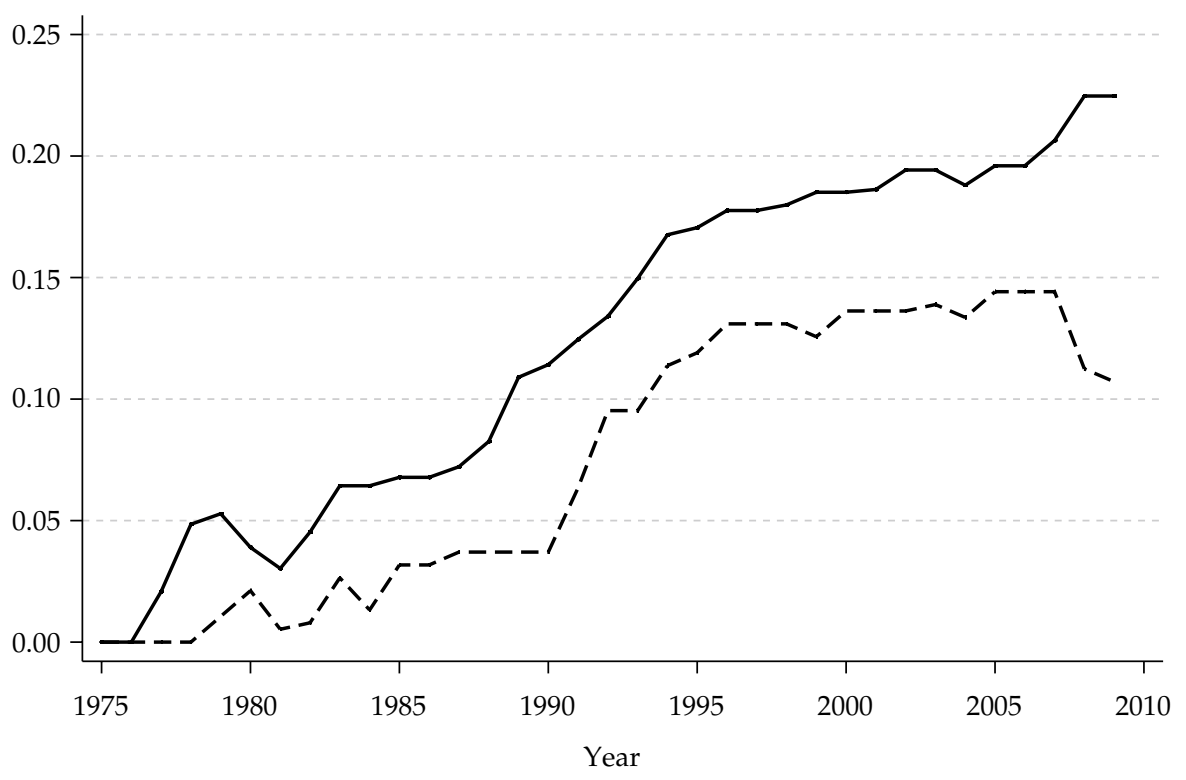

- - - Mean autonomy Mean authority

at the very end of the period might suggest. The dip in autonomy, accompanied by a continued increase in authority, is produced by the appearance, toward the end of the period, of states that approximate the estado de derecho politico model. To illustrate these changes more concretely, I now turn to an analysis of a few representative countries.

The following graph locates a few Latin American courts on these two dimensions, following the evolution of some of them over time (only a few are graphed to allow for legibility). The quadrants are defined by the mean values on each dimension for all the courts of the region for the entire period, to give a sense of what the measurements imply. Thus the courts in the northwest quadrant are above the mean on both dimensions, while those in the southeast are below the mean on both.

If the graph showed all the courts present in 1975, they would all be clustered in the southwest quadrant, where law is both more subject to political control and less pervasive in society. The courts of Chile, Argentina and Nicaragua from that period exemplify this approach to legality (Nicaragua begins even deeper in that quadrant, with the worst scores after Haiti on both dimensions, before moving up and to the right in 1987). Only Costa Rica, Panama, Honduras and Venezuela were (barely) above the mean for scope of authority, and Colombia, pictured here, was the only court that scored above the mean for autonomy in 1975, by about the same margin. These findings are consistent with our general impression of that period as one that is marked by far less legality and far less autonomy for the law. At that time, repression was largely extra-judicial, and when legal 
instances intervened, they mostly legitimized repression, doing little to ameliorate state abuses or equalize social hierarchies. Demands from the left were processed not through law but rather through contentious politics and violent uprisings; the right ran to the barracks, not to the courts, when it felt that the government was exceeding its authority.

Over time, judicial reforms have moved most courts in the region -and, if the courts are an adequate proxy, legality more broadly- in a northeasterly direction, toward greater authority and autonomy, as we can observe in Figure 2. The case of Chile is a paradigmatic example of this move. Consistent with his desire to enshrine and protect certain values from the rigors of an eventual democratic regime, Pinochet's constitution crafted a court that was formally more autonomous than the one under which the junta had been operating, and that had a slightly broader -but not very broad, by later regional standards- scope of authority. Its limited scope of action is consistent with Pinochet's essentially laissez faire approach to economic regulation, but broad enough to protect certain conservative social values and some basic liberal ones. This court, interestingly, was the arbiter of fairness for the plebiscite that ended up dethroning Pinochet before his preferred time (Barros, 2003), suggesting some real, not merely formal, autonomy. The subsequent democratic regime promoted a series of reforms that slowly increased first the scope of the court's authority to reflect the new government's more social democratic aspirations, and then its autonomy. The movement suggested by this purely institutional measure corresponds with more detailed historical accounts of the courts in Chile (Hilbink, 2007; Couso and Hilbink, 2011).

Figure 2: Selected high courts, ranked by institutional autonomy and authority

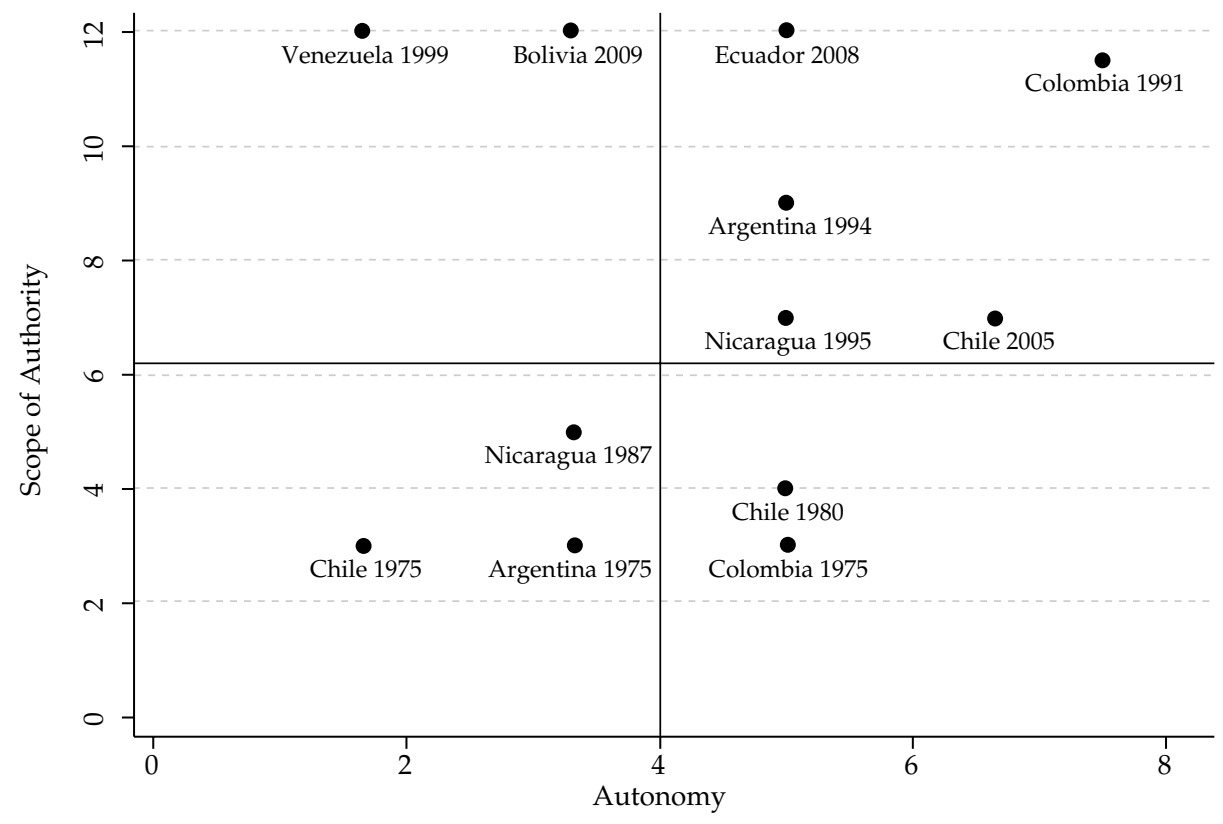


Similarly, Colombia now has one of the most active and powerful courts in the entire region. This country started with a court that enjoyed slightly more autonomy than its neighbors but had a constrained domain under its authority. In practice, of course, the fact that the country was under a nearly constant state of emergency meant that law had an even more limited role in constraining the executive than is suggested by this measure. For decades the courts did nothing to prevent the executive from expanding its discretionary freedom of action. When, in 1991, Colombia adopted its first new constitution in a century, it moved dramatically upward and to the right, toward a much denser legality and a far more autonomous legal system. This movement was prompted in no small part by a rejection of the previous model of unregulated state authority and the lack of legal oversight over public decision making. In this constitution, Colombia made a decision to move from a permanent state of legal exception to a state of legality, and that decision is reflected in the institutional measure. Like Chile but to a much greater degree, Colombia ultimately opted for something approximating an estado social de derecho - a relatively autonomous legal state, with a broad scope of regulation of society and the economy.

Ecuador begins the period, like all the other countries, deep in the southwest quadrant, with a weak, nearly irrelevant legal state. But its many constitutions cast its courts into all quadrants before settling, in the 2008 constitution, for a legal model that has an exceptionally broad remit and is only slightly above the mean in autonomy. In this sense it is roughly in the mold of the 1999 Venezuelan and the 2009 Bolivian constitutions, although the Ecuadorean court appears to have somewhat more autonomy than either of the others. All three of these new constitutional regimes -the self-styled pioneers of the Bolivarian socialist revolution- aim to deeply transform society and regulate the economy, and all three have made extensive use of law and courts to do so.

Venezuela's courts are, de facto, far more controlled than even these lax institutional arrangements would suggest (Pérez Perdomo, 2003; Inter-American Commission on Human Rights, 2009) so in this case the institutional proxy underestimates the extent to which Venezuela has become an estado de derecho politizado. A recent report by the Inter-American Commission on Human Rights provides numerous examples of the use of law in Venezuela to pursue political opponents. For example, protesters are exposed to judicial monitoring and criminal prosecution. "Information received by the Commission indicates that some 120 workers are affected by measures requiring them to report regularly to the courts for having exercised their right of protest" (InterAmerican Commission on Human Rights, 2009: xviii); "the Commission has taken note of numerous cases in which demonstrators have been subjected to criminal trials by virtue of their participation in protests" (p. 38). "As a result of certain declarations made by Mr. Usón [a well-known critic of the government] during a television interview about facts that were the subject of controversy and public debate at that time, criminal proceedings were initiated against him in the military jurisdiction for the crime of insult to the National Armed Forces ... on November 8, 2004, the First Tribunal of Judgment of Caracas (Tribunal Primero de Juicio de Caracas) sentenced him to a prison term of 
5 years and 6 months, along with the accessory penalties of political disqualification for the duration of the sentence" (p. 25). It may be no coincidence that this breakdown in the autonomy of courts is accompanied by an apparently increasing inability to control violence and crime. Bolivia and Ecuador, Venezuela's Bolivarian partners, have not done anything that approaches this level of legalized state repression, but the institutional arrangements hint at a potential for this to happen there too.

As Venezuela illustrates, institutional arrangements do not directly translate into changes in behavior and performance. The proxy is imperfect, and therefore some countries may have either a more or less autonomous or dense legal state than the proxy suggests. At the same time, some positive examples suggest that moderate movements along these two dimensions can have quite dramatic consequences for the nature of the state-as-law. In the late 1970s, of course, Argentina was experiencing one of its worst periods of state terror. Its courts were doing virtually nothing to intervene in the ongoing epidemic of forced disappearances, and semi-autonomous units of the armed forces and the police carried out clandestine state repression. Clearly, this was an extreme example of what I have labeled an "estado politizado". With the restoration of democracy, the formal institutional model did not change, but it became more effective, so that state conduct became far more subjected to the discipline of the law.

Obviously, this move was due to the change of regime, not institutional design. But it soon became evident that the Argentine institutional arrangement was subject to capture by the executive even under democracy, especially when a Peronist president was in office. President Menem's courts soon became infamous for their abject dependence on and favoritism toward the executive (Larkins, 1998; Helmke, 2005) and their inability and unwillingness to control the misuse of power. The existing institutional mechanisms made it relatively easy for Menem's party, which consistently controlled the legislature, to expand the high court and the lower courts and name cronies to the bench, and an informal practice of replacing Supreme Court judges with every change in government made it even easier to craft a friendly court (Kapiszewski, 2012). The 1994 constitutional reforms offered the opposition an opportunity to change all this. Menem wanted a constitutional amendment that would allow for his reelection; in exchange, the political opposition, under former president Alfonsín, negotiated a series of reforms that were meant to curtail the president's powers. Figure 2 reflects the effects of the 1994 negotiations on the judicial system, registering them as a significant increase in both autonomy and the scope of authority of the courts.

These modest reforms led to a quite significant transformation of the judiciary and, potentially, the nature of legality more broadly -although it is quite clear that this deeper transformation remains a pending assignment. The reforms required public hearings and a two-thirds vote in the Senate for approval of the president's nominees to the Supreme Court; they added significantly to the court's formal powers, by making a broad array of rights justiciable, and, importantly, by giving international human rights treaties constitutional status; and they made a few other changes that increased the transparency of the court's operation. Once those provisions had the chance to operate -that is, once a new set of justices had been appointed under the new procedures- the Supreme Court of 
Argentina began a much more activist and progressive phase, making extensive use of the new rights to challenge a broad range of government policies (Brinks, 2005; Bergallo, 2005). The result is that, at least in certain areas that have become constitutionalized, public decision-making is more closely subjected to legal standards.

In Argentina, the broader transformation of legality beyond the courts is stymied by failures at the level of the lower courts. At the lower court level, the constitutional changes introduced a judicial council for appointments to the bench and to discipline sitting judges, removing these faculties from the direct control of the president and senate. This potentially important mechanism has, however, been handicapped, first by the failure to begin operations for a decade, and more recently by blatant attempts by the Kirchner and Fernández administrations to control the Council. This failure to transform lower courts is one of many reasons why the transformation of the state-aslaw has failed to penetrate much deeper than the Supreme Court.

\section{AUTONOMY, DENSITY AND STATE CAPACITY}

What do these transformations of the state-as-law mean for state capacity in Latin America? Each of these dimensions is positively related to state strength. Paradoxically, with greater autonomy, law both constrains governmental and state actors and makes the state itself stronger, in the sense that it is more crisply devoted to carrying out (de jure) state purposes. Much of the literature on state capacity focuses on the capacity of the state to control or provide services to citizens -make them pay their taxes, keep them from stealing from each other, provide education or a solid legal and physical infrastructure for economic development. But if it is true that making the state order effective is an integral aspect of state capacity, then we should consider that a state that violates its formal obligations to its citizens is a weaker state than one that can successfully discipline all its agents to constitutional standards, for example. Thus a police force that carries out a large number of formally illegal extrajudicial executions is a manifestation of state weakness, not state strength. Such a state is unable to subject even its agents to the duties inscribed in its own order.

In many models the state is assumed to be monolithic and this control over the actions of the state is assumed to be a task for the citizenry, to be exercised through elections, or, if that fails, revolution. Weingast (1997) is perhaps the clearest example. But courts (that is, state institutions) are the more routine way to check the conduct of individual state actors -even executives. In fact, much intra-electoral horizontal accountability is exercised by state officials, often in response to social demands, with one part of the state holding another to official state purposes (O'Donnell, 2003; Mainwaring and Welna, 2003; Smulovitz and Peruzzotti, 2003). Clearly, a crucial element in a "democratic" rule of law is the ability to hold the government to pre-existing rules; to ensure, as O'Donnell puts it, that no one is "de legibus solutus" (O'Donnell, 2010). As noted in the definitional section of this article, a proceduralist version of this is a crucial requirement for the rule of law to exist at all, and not just for a democratic rule of law. If we accept this, then the key point is that the state, especially the state-as-law, is stronger when it can hold 
even its own agents to the rules in the state's order- and this requires what we might call legal autonomy (which rests in part on, but is not identical to, what is commonly referred to as judicial independence). In this view, the high autonomy cases in Table 2 are higher rule of law states, and have a state that is more tightly focused on carrying out the state purposes that are expressed in law.

Density interacts with autonomy to produce different levels of state strength. The Thick Rule of Law states subject more social, economic and political decisions to legal and constitutional standards in all four cells of Table 1, producing both a larger regulatory state and one that is more accountable. The Thin Rule of Law states, in turn, with their smaller regulatory state, leave more policy outcomes to be determined by the market or currently dominant social and political forces. Arguably, the former are building stronger states, at least in the sense that the states do more work, but both are creating an effective rule of law.

At the opposite end of the autonomy continuum, countries that opt for low levels of autonomy signal that law and courts are instruments of the current government. The high density countries among them -the ones choosing politicized legalism, in the above table- are also building state strength, especially relative to the extra-legal states, but in these cases the state-as-law is more of a vehicle for the current government to implement its agenda, regardless of constitutional or other standards. These states have less autonomy from the current government, less rule of law, and should be considered weaker. Finally, the countries where courts have neither autonomy nor a broad scope of action, suggesting that law and courts are simply not relevant to most high-level decision making, are likely to have the weakest states. They are neither using the courts to project power, nor subjecting that power to the discipline of the law. In these cases, we would expect more power to be exercised either through para-state means, or through less accountable state agents -the armed forces, for example, which tend to be less subject to legal and judicial oversight.

I have just suggested that the states with an estado social de derecho are the strongest states. I do not mean to suggest by this that the ideal state should regulate every interaction and run every decision past a high court of some sort. Indeed, there is a vast normative and empirical debate underlying the question of just how much density of regulation is good for individual freedom and equality, economic development and social welfare, and many more crucially important dimensions of politics, the economy and social relationships. Too much judicial intervention can lead to paralysis and, depending on the nature of the judiciary, can detract from democratic decision making. State strength and the rule of law may come at the expense of personal (and economic) freedom. State overreaching in trying to change entrenched social norms and practices may lead to failure and a backlash. Every society must debate and decide on the proper balance between state and society, regulation and laissez faire, aspirational state policies in pursuit of the common good and individual choices no matter how unpopular.

My point here is more modest. As an empirical matter, it seems clear that we are observing a fairly deep transformation in Latin America in the scope and autonomy of state legality. Also as an empirical matter, it seems uncontestable that those states that are 
experimenting with the higher reaches on each of these dimensions are the "stronger" ones. As a result, assuming the Brinks and Blass measures of autonomy and authority capture the sincere preferences and intent of the designers, it appears that, on average, the constitutions and constitutional reforms enacted in Latin America since 1975 have sought to promote state capacity. They seem to embody a vision of the state that is more congruent with a strong rule of law, the resolution of social conflict through legal means, and rule-bound governments.

In summary, this exercise suggests that the new political reality in Latin America is leading to new kinds of states-as-law. This may be due in part to a post-Cold War context in which both international and domestic actors increasingly frown upon purely extralegal action. It may be related to the natural affinity between higher levels of democracy and the kind of political competition that allows ambition to check ambition. And it may be connected to socio-economic developments that are improving the capacity of marginalized groups to engage with the state using formal legal mechanisms. Regardless of their origin, these new ideal types have different implications for state strength, understood as the capacity (and inclination) of governments to act through state actors, in accordance with the state purposes specified in the legal order.

Some countries -those with a more social democratic agenda, and a more pluralistic and programmatic party system- are building a stronger "estado social de derecho", with more ambitious state purposes. Others, with a stronger market orientation, are opting for a leaner "estado liberal de derecho", leaving more interactions to the logic of the market. Meanwhile, some of the countries in the region are building powerful judiciaries that are vehicles for a partial, executive-dominated style of legalized political decision makingan "estado de derecho politizado". More and more, it seems, countries are abandoning the old model, in which courts and law were relatively tangential to the exercise of political power, and social, economic and coercive power ruled. Where this transformation is most profound, the brown areas described by O'Donnell (1993) are slowly and imperfectly giving way to the prevalence of state order across geographic and socio-economic spaces.

This should be good news, even with the important caveat that law is, and always has been, a friend of the powerful, and when it loses autonomy can be a very efficient and effective tool of repression. A state based on law, with autonomous courts, can reduce arbitrary action, impose a certain discipline and predictability, and create openings even for the least powerful in a society. Such a state is, in its legal dimension at least, a stronger state than one that is simply bypassed whenever the powerful want to pursue their interests without constraint. When a state chooses to repress through law, using tightly controlled legal mechanisms and ad hoc applications of the law to political opponents, much of the benefit is lost. Still, there seems to be more room for voice and resistance when a state is channeling repression through legal mechanisms than through alternative means - it seems preferable to be arrested and tried, even on trumped up charges, than forcibly disappeared.

This analysis raises many questions for future research. The most obvious is, of course, what leads a country to move in the direction of one of the four ideal types of legal states? What has changed in the region to move both governments and challengers toward the 
use of law for pressing and responding to demands? Another question, perhaps more important from a policy perspective, is the likely effect of the current wave of violence on these new legal states. What implications flow from the fact that in certain places organized crime can outgun, outspend, and even infiltrate and control the state? What might it look like when this new emphasis on legal forms is put at the service of organized crime? A third question concerns the likely effects of this change for different social groups. Does law have the potential, as many of these groups seem to believe, for really transforming society, or is it, as some have argued, mostly a "flytrap" (Rosenberg, 2008) leading advocates of change to waste their resources on a mirage? Is law more easily hijacked into the service of privilege than, say, legislative politics, or does it level the playing field in some way? The answer to these questions is by no means clear. What is clear is that one can no longer understand the evolution of politics and policies in Latin America without taking into account the way in which legal language, tools and spaces now structure social demands, state responses, and public decision making.

\section{REFERENCES}

Barros, Robert. 2003. "Dictatorship and the Rule of Law: Rules and Military Power in Pinochet's Chile". In Democracy and the Rule of Law, ed. J. M. Maravall and A. Przeworski. Cambridge: Cambridge University Press.

Bergallo, Paola. 2005. “Justice and Experimentalism: The Judiciary's Remedial Function in Public Interest Litigation in Argentina". SELA (Seminario en Latinoamérica de Teoría Constitucional y Política) Papers. Paper 44. http://digitalcommons.law.yale.edu/yls_sela/44

Blass, Abby and Daniel M. Brinks. 2011. "The Institutional Roots of Judicial Power: Latin America from 1975 to 2009". In Annual Meeting of the American Political Science Association. Seattle, Washington.

Brinks, Daniel and Abby Blass. 2011a. "International pressures and Potemkin courts: Real and apparent purposes in the construction of Latin American courts, 1975-2009." Paper presented at the Conference "Ruling Politics: the Formal and Informal Foundations of Power in New Democracies", Harvard University, November 21-22, 2011.

Brinks, Daniel M. 2005. "Judicial Reform and Independence in Brazil and Argentina: The Beginning of a New Millennium?". Texas International Law Journal 40 (3 [Spring]): 595-622.

Brinks, Daniel M. 2008. "Inequality, institutions and the rule of law: the social and institutional bases of rights". Kellogg Institute Working Paper Series (351).

Brinks, Daniel M. and Abby Blass. 2011b. "Designing Courts for Governance: the political origins of powerful courts". Unpublished - available upon request from authors. Austin, TX.

Brinks, Daniel M. and Sandra Botero. forthcoming. "The Social and Institutional Bases of the Rule of Law". In Notes for the Study of Imperfect and Uncertain Democracies: The Legacy of Guillermo O'Donnell, ed. D. M. Brinks, S. Mainwaring and M. Leiras. Baltimore, MD: Johns Hopkins University Press.

Couso, Javier and Elisabeth C. Hilbink. 2011. "From quietism to incipient activism: the institutional and ideational roots of rights adjudication in Chile". In Courts in Latin America, ed. J. Rios-Figueroa and G. Helmke. New York: Cambridge University Press.

Couso, Javier, Alexandra Huneeus and Rachel Sieder, eds. 2010. Cultures of Legality: Judicialization and Political Activism in Latin America. Cambridge, New York: Cambridge University Press.

Domingo, Pilar and Rachel Sieder, eds. 2001. Rule of Law in Latin America: The International Promotion of Judicial Reform. London: Institute of Latin American Studies.

Ellickson, Robert C. 1991. Order Without Law: How neighbors settle disputes. Cambridge: Harvard University Press. French, John D. 2004. Labor Law and Brazilian Political Culture: Drowning in Laws. Chapel Hill, NC: University of North Carolina Press. 
Gauri, Varun and Daniel M. Brinks, eds. 2008. Courting Social Justice: Judicial Enforcement of Social and Economic Rights in the Developing World. New York: Cambridge University Press.

Ginsburg, Tom and Tamir Moustafa. 2008. Rule by law: the politics of courts in authoritarian regimes. Cambridge UK ; New York: Cambridge University Press.

Hamilton, Alexander, James Madison and John Jay. 1961. The Federalist Papers. Edited by C. Rossiter. New York: Mentor (Penguin Books).

Hart, H.L.A. 1961. The Concept of Law. Oxford: Clarendon Press.

Helmke, Gretchen. 2005. Courts under constraints: Judges, Generals and Presidents in Argentina. New York: Cambridge U Press.

Hilbink, Lisa. 2007. Judges beyond politics in democracy and dictatorship: lessons from Chile. New York: Cambridge University Press.

Holmes, Stephen. 2003. "Lineages of the Rule of Law". In Democracy and the Rule of Law, ed. J. M. Maravall and A. Przeworski. Cambridge: Cambridge University Press.

Inter-American Commission on Human Rights. 2009. "Democracy and Human Rights in Venezuela".

Kapiszewski, Diana. 2012. High Courts and Economic Governance in Argentina and Brazil. New York: Cambridge University Press.

Kleinfeld, Rachel. 2006. "Competing Definitions of the Rule of Law". In Promoting the Rule of Law Abroad: In Search of Knowledge, ed. T. Carothers. Washington, D.C.: Carnegie Endowment for International Peace.

Larkins, Christopher M. 1998. "The Judiciary and Delegative Democracy in Argentina". Comparative Politics 31 (July): 423-442.

Levi, Margaret. 1988. Of Rule and Revenue. Berkeley: University of California Press.

Mainwaring, Scott and Christopher Welna, eds. 2003. Democratic Accountability in Latin America. Oxford: Oxford University Press.

Maravall, José María and Adam Przeworski, eds. 2003. Democracy and the Rule of Law. Cambridge: Cambridge University Press.

Méndez, Juan E., Guillermo A. O'Donnell and Paulo Sérgio Pinheiro, eds. 1999. The (Un)Rule of Law and the Underprivileged in Latin America. Notre Dame, IN: University of Notre Dame Press.

Moustafa, Tamir. 2003. "Law versus the State: The Judicialization of Politics in Egypt". Law \& Social Inquiry 28 (4): 883-930.

O'Donnell, Guillermo A. 1993. "On the State, Democratization and Some Conceptual Problems: A Latin American View with Glances at Some Postcommunist Countries". World Development 21 (8): 1355-1369.

O'Donnell, Guillermo A. 1994. "Delegative Democracy". Journal of Democracy 5: 55-69.

O'Donnell, Guillermo A. 2001. "Democracy, Law and Comparative Politics". Studies in Comparative International Development 36 (1 [Spring]): 7-36.

O'Donnell, Guillermo A. 2003. "Horizontal Accountability: The Legal Institutionalization of Mistrust". In Democratic Accountability in Latin America, ed. S. M. a. C. Welna. Oxford: Oxford University Press.

O'Donnell, Guillermo A. 2004. "Why the Rule of Law Matters". Journal of Democracy 15 (4): 32-46.

O'Donnell, Guillermo A. 2010. Democracy, Agency, and the State : Theory with Comparative Intent. Oxford and New York: Oxford University Press.

Pereira, Anthony W. 2005. Political (in)justice: authoritarianism and the rule of law in Brazil, Chile, and Argentina. Pittsburgh, Pa.: University of Pittsburgh Press.

Pérez Perdomo, Rogelio. 2003. "Venezuela 1958-1999: The Legal System in an Impaired Democracy". In Latin Legal Cultures in the Age of Globalization. Latin Europe and Latin America, ed. L. M. Friedman and R. Pérez Perdomo. Stanford: Stanford University Press.

Rawls, John. 1971. A Theory of Justice. Cambridge, MA: Belknap Press.

Raz, Joseph. 1979. "The Rule of Law and its Virtue". In Liberty and the Rule of Law, ed. R. L. Cunningham. College Station, Texas: Texas A\&M University Press.

Rodríguez Garavito, César. 2010. "Toward a Sociology of the Global Rule of Law Field: Neoliberalism, Neoconstitutionalism and the Contest over Judicial Reform in Latin America". In Lawyers and the Trasnationalization of the Rule of Law, ed. B. Garth and Y. Dezalay. New York: Routledge.

Rodríguez Garavito, César and Diana Rodríguez Franco. 2010. Cortes y Cambio Social: Cómo la Corte Constitucional transformó el desplazamiento forzado en Colombia. Bogotá, Colombia: Dejusticia. 
Rosenberg, Gerald N. 2008. The hollow hope: can courts bring about social change? 2nd ed. Chicago: University of Chicago Press.

Rosenn, Keith S. 1987. "The Protection of Judicial Independence in Latin America". Inter-American Law Review 19 (1): 1-35.

Santos, Alvaro. 2006. "The World Bank's uses of the "Rule of Law" promise in economic development". In The new law and economic development: A critical appraisal, ed. D. Trubek and A. Santos. New York: Cambridge University Press.

Segal, Jeffrey and Harold Spaeth. 2002. The Supreme Court and the Attitudinal Model Revisited. Cambridge: Cambridge University Press.

Sieder, Rachel, ed. 2002. Multiculturalism in Latin America: indigenous rights, diversity, and democracy. Houndmills, Basingstoke, Hampshire; New York: Palgrave Macmillan.

Sieder, Rachel, Line Schjolden and Alan Angell, eds. 2005. The Judicialization of Politics in Latin America. New York: Palgrave Macmillan.

Smulovitz, Catalina and Enrique Peruzzotti. 2003. "Societal and Horizontal Controls: Two Cases of a Fruitful Relationship". In Democratic Accountability in Latin America, ed. S. Mainwaring and C. Welna. Notre Dame: University of Notre Dame Press.

Stone Sweet, Alec. 1999. "Judicialization and the Construction of Governance". Comparative Political Studies 32 (2): 147-184.

Tomlins, Christopher. 2007. "How Autonomous is Law?" Annual Review of Law and Social Science 3: 45-68.

Trebilcock, M. J. and Ronald J. Daniels. 2008. Rule of law reform and development: charting the fragile path of progress. Cheltenham, UK; Northampton, MA, USA: Edward Elgar.

Tyler, Tom R. 2006. Why people obey the law. Princeton, N.J.: Princeton University Press.

Weber, Max. 1978. Economy and society: an outline of interpretive sociology. Translated by E. Fischoff, H. Gerth, A. M. Henderson, F. Kolegar, C. W. Mills, T. Parsons, M. Rheinstein, G. Roth, E. Shills and C. Wittich. Edited by G. Roth and C. Wittich. 2 vols. Vol. 2. Berkeley: University of California Press.

Weingast, Barry R. 1997. "The Political Foundations of Democracy and the Rule of Law". American Political Science Review 91 (2): 245-263.

Yamin, Alicia Ely and Siri Gloppen, eds. 2011. Litigating Health Rights: Can Courts Bring More Justice to Health? Cambridge, MA: Harvard University Press.

Daniel M. Brinks is Associate Professor in the Government Department and the Law School, at the University of Texas, and serves as co-director of the Rapoport Center for Human Rights and Justice. He has a PhD in Political Science from the University of Notre Dame, and a J.D. from the University of Michigan Law School. His research focuses on the role of the law and courts in guaranteeing democratic and constitutional rights, with a primary regional interest in Latin America. E-mail: danbrinks@gov.utexas.edu 
